\title{
Freedom and Access to Housing: Three Conceptions
}

\section{Terry Skolnik*}

This article argues that our current understanding of the relationship between access to housing and liberty (or freedom) is limited. It contends that judicial decisions and existing legal theory are predominantly concerned with the connection between housing and the two conceptions of liberty famously advanced by Isaiah Berlin: positive liberty and negative liberty. The notion of positive freedom conceptualizes freedom as self-mastery, whereas negative liberty portrays freedom as non-interference.

The central premise of this article is that the republican theory of freedom (or republicanism) provides new insight into the importance of access to housing in protecting liberty, most notably in contexts where the state regulates public property, such as in Canada and the United States. The republican theory of freedom defines liberty as nondomination, meaning the absence of others' power to interfere with an individual's life and actions. This article argues that we develop a more well-rounded grasp of the value of access to housing by understanding its role in protecting individuals against domination. This article concludes by setting out the four concrete ways that housing reduces domination and safeguards individual freedom in contexts where the state regulates public property. By combining the respective insights of positive liberty, negative liberty, and republican liberty, this article ultimately provides a more robust understanding of the importance of housing in protecting freedom.

Dans cet article, l'auteur soutient que notre compréhension actuelle de la relation entre l'accès au logement et la liberté est limitée. Il affirme que les décisions judiciaires et la théorie actuelle du droit s'intéressent avant tout à la relation entre le logement et les deux célèbres conceptions de la liberté formulées par Isaiah Berlin : la liberté positive et la liberté négative. La notion de liberté positive présente la liberté comme la maîtrise de son sort, tandis que la liberté négative décrit la liberté comme l'absence d'ingérences.

La proposition centrale de cet article est que la théorie républicaine de la liberté (ou républicanisme) jette une lumière nouvelle sur l'importance de l'accès au logement pour la protection de la liberté. La théorie républicaine de la liberté la définit comme la nondomination, c'est-à-dire l'absence de pouvoirs externes d'entraver la vie et les actes de quelqu'un. L'argument fondamental de l'article est que le républicanisme corrige certaines lacunes des théories qui étudient l'importance de l'accès au logement du seul point de vue de la liberté négative et de la liberté positive. Nous parvenons à une compréhension plus solide de l'importance du logement en percevant son rôle de protection des personnes contre la domination. Après avoir examiné la prévalence croissante des règles applicables à la propriété commune et la manière dont l'accès au logement détermine l'influence de ces règles sur la vie d'une personne, l'auteur conclut l'article en présentant les quatre manières concrètes dont le logement réduit la domination et protège ainsi la liberté individuelle. 


\section{INTRODUCTION}

When we think about access to housing, we understand its fundamental role in protecting a range of basic values and interests. Housing provides physical protection from the elements and from unwanted intrusions by others. ${ }^{1}$ Within the walls of a house or apartment, people benefit from an important degree of privacy that they lack in public places. ${ }^{2}$ An individual's personhood and identity are deeply tied to their home: ${ }^{3}$ the home is frequently the centre of family life, personal growth and development, and it often anchors a person's most cherished and painful memories. ${ }^{4}$

It is therefore no surprise that scholars and courts often remark that housing fosters dignity, autonomy, liberty, and human flourishing. ${ }^{5}$ Housing affords one of the highest expectations of privacy in law. ${ }^{6}$ Consequently, police officers must obtain warrants to conduct a search within a dwelling house. ${ }^{7}$ Those who have a private property right possess the power to exclude others and have trespassers removed, endowing individuals with a sphere of liberty where they can live free from unwanted intrusions by others. $^{8}$

This article focuses on the connection between access to housing and one value in particular: freedom (or liberty - the terms are used interchangeably). It contends that much of our understanding of how access to housing protects individual liberty is rooted in the classic distinction between positive and negative freedom famously advanced by Isaiah Berlin. ${ }^{9}$ According to that distinction, positive freedom is associated with the notion of self-mastery and rational self-determination..$^{10}$ The positive conception of liberty is

* Assistant Professor, University of Ottawa, Faculty of Law (civil law section). Affiliated scholar at the NYU Center for Human Rights and Global Justice (CHRGJ). I would like to thank the SSHRC for their generous financial support, the CHRGJ community and the 2017 Housing Law Symposium in Malmö, Sweden, for their helpful support and comments on a prior draft, as well as Professor Jeremy Waldron who commented at length on that prior draft. I would also like to thank Deborah Popowski, Rehan Abeyratne, Aoife Nolan, Zelalem Kibret, Francesco Presciutti, Malcolm Thorburn, Jacob Weinrib, Alon Harel, Vincent Chiao, Christopher Essert, Anna Maria Konewka, and the anonymous reviewers for their helpful feedback that improved this article. All mistakes are my own.

1 Benjamin Barros, "Home as a Legal Concept" (2005-2006) 46 Santa Clara L Rev 255 at 259-60.

2 Kristen David Adams, "Do We Need a Right to Housing?" (2009) 9 Nevada LJ 275 at 307.

3 Margaret Jane Radin, "Property and Personhood" (1982) 34 Stan L Rev 957 at 967. In this article, the term "home" is used to connote a permanent form of shelter over which an individual has a private property right. This includes, but is not limited to, a house, apartment, dorm room, and mobile home.

4 Ibid.

5 Gregory Alexander \& Eduardo Peffalver, "Properties of Community" (2009) 10 Theor Inq L 127 at 154-5. See also: Chameli Singh v State Of U.P (1996) 2 SCC 549 (Supreme Court of India) at para 8; Jessie Hohmann, The Right to Housing: Law, Concepts, Possibilities (London: Hart Publishing, 2013) at 126 citing Francis Coralie Mullin v The Administrator, Union Territory of Delhi \& Ors.1981 AIR 746, 1981 SCR (2) 516 (Supreme Court of India).

$6 \quad R v$ Evans [1996] 1 SCR 8 at para 35 (per Sopinka J); $R v$ Tessling [2004] 3 SCR 432 at para 22, 2004 SCC 67. Both cases cited in $R v$ Patrick, 2009 SCC 17 at para 44, 1 SCR 579; Justin Stec, "Why the Homeless Are Denied Personhood under the Law: Toward Contextualizing the Reasonableness Standard in Search and Seizure Jurisprudence" (2006) 3 Rutgers JL \& Urb Pol'y 321 at 322-3.

$7 \quad R v$ Wong [1990] 3 SCR 36 [requirement of a general warrant for surveillance within a dwelling house]. See also: $R v$ Feeney [1997] 2 SCR 13 at paras 37-38 [requirement of an arrest and entry warrant to arrest a person within their dwelling house, and to search a person's dwelling house].

$8 \quad$ Morris R Cohen, "Property and Sovereignty" (1927) 13 Cornell L Rev 8 at 12.

9 Isaiah Berlin, "Two Concepts of Liberty" in Berlin, Four Essays on Liberty (Oxford: Oxford University Press, 1969) 118.

10 Ibid at 131-3; John Gray, "On Negative and Positive Liberty" (1980) 28 Political Studies 507 at 518; Lester Crocker, "Rousseau's Soi-Disant Liberty" in Robert Wokler, ed, Rousseau and Liberty (Manchester: Manchester University Press, 1995) 244. 
often tied to deeper questions about government's role and duties to maximize opportunities and promote self-actualization. ${ }^{11}$ Negative freedom, on the other hand, construes liberty as the absence of interference by others. ${ }^{12}$ The negative conception of liberty is reflected in the constitutional law of Western democracies, as constitutional rights predominantly afford protection against interferences by the state. ${ }^{13}$

This article argues that our current comprehension of the relationship between freedom and access to housing is incomplete. This article's central premise, is that we attain a more robust and well-rounded understanding of the connection between housing and freedom by also appealing to a third conception of liberty: republicanism (or the republican theory of freedom). ${ }^{14}$ While negative freedom implies noninterference and positive freedom connotes self-mastery, republicanism construes freedom as nondomination. ${ }^{15}$ Non-domination means that others lack a power or possibility to interfere with an individual's life, actions, and purposes. ${ }^{16}$ By uniting the respective insights of positive liberty, negative liberty, and republican liberty, we gain a more complete picture of housing's role in protecting individual freedom. Indeed, all three conceptions of freedom play a crucial but different role in understanding the importance of access to housing, especially in states that both regulate public property and have a private property regime embedded with a strong private power to exclude others.

In this article, the term "homelessness" and "lack of access to housing" (or similar phrases) are used interchangeably, and for the purposes of this article, a person who lacks access to housing is experiencing homelessness. ${ }^{17}$ This article therefore adopts the definition of homelessness set out by the Canadian Homelessness Research Network [CHRN]. According to the CHRN:

Homelessness describes the situation of an individual or family without stable, permanent, appropriate housing, or the immediate prospect, means and ability of acquiring it. It is the result of systemic or societal barriers, a lack of affordable and appropriate housing, the individual/household's financial, mental, cognitive, behavioural or physical challenges, and/or racism and discrimination. Most people do not choose to be homeless, and the experience is generally negative, unpleasant, stressful and distressing. ${ }^{18}$

It is also necessary to point out that there are different typologies of homelessness and to issue an important caveat. ${ }^{19}$ This article's arguments apply with the greatest force in contexts where individuals are experiencing certain typologies of homelessness, most notably where individuals are unsheltered, staying

11 David Nichols, "Positive Liberty, 1880-1914" (1962) 56 Am Pol Sci Rev 114 at 117; Joanna Duke, "Exploring Homeowner Opposition to Public Housing Developments" (2010) 37 J Sociol \& Soc Welfare 49 at 55-6.

12 Berlin, supra note 9 at 122.

13 Frank Cross, "The Error of Positive Rights" (2000-2001) 48 UCLA L Rev 857 at 872.

14 Phillip Pettit, Republicanism: A Theory of Freedom and Government (Oxford: Oxford University Press, 1999) [Pettit, Republicanism]; Philip Pettit, On the People's Terms: A Republican Theory and Model of Democracy (Cambridge: Cambridge University Press, 2013) [Pettit, On the People's Terms].

15 Pettit, Republicanism, ibid at 22-23.

16 Ibid.

17 This choice of terminology is not intended to negate the possibility that some who are living on the streets may in fact be able to access some form of housing (though it may be inadequate), nor the inverse possibility that some who have access to shelter, such as that provided rent-free by friends or family, may not truly have access to housing in the fullest sense of the term, as the only thing separating them from spending their days or nights on the streets is the revocable permission of said friends or family (See Essert infra note 24). In each of those cases, domination still persists in a person's life, although to varying degrees that can fluctuate in intensity and frequency according to a person's circumstances.

18 Stephen Gaetz, Tanya Gulliver, \& Tim Richter, “The State of Homelessness in Canada: 2014” (Toronto: The Homeless Hub Press, 2014) at 38, citing the CHRN definition of homelessness.

19 Ibid at 39. 
in emergency shelters, or are provisionally accommodated in some private place that offers no prospect of permanency or security of tenure (e.g.: staying with friends or in some other temporary accommodation) ${ }^{20}$ Conversely, those same arguments will apply with less force in contexts where individuals have access to some form of housing, but that form of housing is inadequate.

As will be explained, when the state regulates public property and individuals lack access to housing, both the state and others unilaterally wield power over those individuals in ways that are antithetical to any meaningful conception of liberty and equality. ${ }^{21}$ In both Canada and the U.S., laws and ordinances that regulate public property prohibit individuals from engaging in certain acts, such as sleeping, urinating, defecating, and lying down on public property. ${ }^{22}$ Without access to housing, an individual's ability to obey those laws will increasingly be delegated to others and placed outside of their control. ${ }^{23}$ Yet in a form of self-fulfilling prophecy, a person who lacks access to housing will often violate those laws, which in turn provides the state with legitimate reasons to regulate their most basic human acts in the first place. In such contexts, others can dominate that individual in a variety of ways, even if others do not concretely obstruct that individual's actions. ${ }^{24}$ This article therefore provides new insight into how access to housing not only promotes positive and negative liberty, but also maximizes republican liberty by reducing domination.

This article is structured as follows. Section II explores access to housing through the lens of positive freedom. Section III discusses the role of access to housing in protecting negative liberty and outlines certain limitations to that approach. Section IV argues that by approaching access to housing and the regulation of public property from the standpoint of republicanism, we are afforded new insight into how housing safeguards liberty by preventing domination. ${ }^{25}$ Section V concludes this article, by demonstrating four practical implications of this article's core argument and highlights the importance of access to housing in protecting positive, negative, and republican conceptions of freedom.

\section{POSITIVE LIBERTY AND ACCESS TO HOUSING}

\section{A. Positive Liberty}

There are different conceptions of positive freedom. ${ }^{26}$ This article adopts the influential account advanced by Berlin, which construes positive liberty as self-mastery. ${ }^{27}$ Positive freedom implies self-rule,

20 Ibid. Those typologies of homelessness are also mentioned in the CHRN definition of homelessness.

21 This argument was first advanced in: Terry Skolnik, "How and Why Homeless People Are Regulated Differently" (2018) 43 Queen's LJ 297 [Skolnik, "Regulated Differently"].

22 NLCHP, "Housing Not Handcuffs: Ending the Criminalization of Homelessness in U.S. Cities" (Washington: 2016) at 21-22; Celine Bellot \& Marie-Eve Sylvestre, "La judiciarisation de l'itinérance à Montréal: les dérives sécuritaires de la gestion pénale de la pauvreté" (2017) 42 RGD 11 at 23.

23 Skolnik, "Regulated Differently", supra note 21 at 310.

24 This argument has also been advanced more recently in Christopher Essert, "Property and Homelessness" (2016) 44 Phil \& Pub Aff 266.

25 Ibid.

26 See e.g. Oren Ben-Dor, Constitutional Limits and the Public Sphere: A Critical Study of Bentham's Constitutionalism (London: Hart, 2000) at 256; John Christman, "Liberalism and Individual Positive Freedom" (1991) 101 Ethics 343 at 344-345.

27 David Abraham, "Liberty without Equality: The Property-Rights Connection in a Negative Citizenship Regime" (1996) 21 Law \& Soc. Inquiry 1 at 19. [The term "freedom $t o$ " is italicized in the original text]. As Kramer points out, there are varying descriptions of what the term "positive liberty" entails. See Matthew Kramer, The Quality of Freedom (Oxford: Oxford University Press, 2003) at 96. 
the attainment of one's "higher," "real," or "rational" self, and the control of one's impulses. ${ }^{28}$ In some ways, positive liberty is tied to complicated metaphysical questions about rational agency and individual capacity. ${ }^{29}$ It revolves around a person's abilities to control themselves, improve their character and disposition, and self-actualize. ${ }^{30}$

But it is also a mistake to think of the notion of positive liberty as something entirely internal to the agent and free of external constraints. There is a connection between positive freedom and the existence of options, choices, and infrastructure that allow individuals to self-actualize. ${ }^{31}$ Positive liberty therefore tends to be concerned with the allocation of resources and the government's role in the distribution of those resources. ${ }^{32}$ For that reason, positive liberty is often tethered to larger political questions about the role and effectiveness of state institutions in optimizing human flourishing. ${ }^{33}$ While positive liberty gravitates around notions of ability, agency, and potential, it also recognizes that a person's self-fulfillment will be limited if they do not have access to certain basic resources and infrastructure. This explains the connection between positive liberty and positive rights, meaning rights that give rise to the state's affirmative duty to provide individuals with certain rudimentary entitlements. ${ }^{34}$ If human beings are to flourish and reach their potential, yet lack the means to do so, maximizing positive liberty requires the state to provide entitlements that achieve those aims. ${ }^{35}$

\section{B. Access to Housing and Self-Actualization}

Some courts have drawn a connection between the right to housing and the promotion of positive liberty. The Constitution of South Africa expressly provides a right to adequate housing and a series of decisions have explored its underlying basis. ${ }^{36}$ In Grootboom, the Constitutional Court of South Africa explained that access to housing fosters human dignity, freedom, and equality. ${ }^{37}$ In the Court's view in Grootboom, access to housing is necessary to promote the "evolution of a society in which men and women are equally able to achieve their full potential." "38 Similarly, in the Joe Slovo (I) decision, that same Court concluded that housing allows people to live free and independent lives, and confers opportunities that did not exist for many people during the Apartheid era. ${ }^{39}$ To be clear, this does not mean that the

28 Berlin, supra note 9 at 132; Lawrence Crocker, Positive Liberty: An Essay in Normative Political Philosophy (The Hague: Martinus Nijhoff, 1980) [Crocker, Positive Liberty] at 2; Ben-Dor, supra note 26 at 226-27.

29 See the analysis of Green's work in: John Deigh, Emotions, Values, and the Law (Oxford, Oxford University Press, 2008) at 224.

30 Thomas H Green, “On the Different Senses of 'Freedom' as Applied to Will and to the Moral Progress of Man” in Thomas Green, Lectures on the Principles of Political Obligation (London: Longmans, Green, and Co, 1937) at 2-4; Horacio Spector, "Four Conceptions of Freedom" (2010) 38 Political Theory 780 at 784. Some have noted that there is a connection between positive liberty and certain philosophical traditions such as stoicism. See George Crowder, Isaiah Berlin: Liberty and Pluralism (Cambridge: Polity, 2004) at 69-70.

31 Ben-Dor, supra note 26 at 256-7.

32 Ibid.

33 Crocker, Positive Liberty, supra note 28 at 2.

34 Lynn A Baker, "Prices of Rights: Toward a Positive Theory of Unconstitutional Conditions" (1990) 75 Cornell L Rev 1184 at $1217-8$.

35 Ibid.

36 Constitution of the Republic of South Africa, 1996, s. 26.

37 Government of the Republic of South Africa and Others v Grootboom and Others, 2001 (1) SA 46 (CC), at para 23.

38 Ibid.

39 Residents of Joe Slovo Community, Western Cape v Thubelisha Homes and Others, 2010 SA 454 (CC), at paras 191-92. Other cases have rooted the philosophical importance of housing in the notion of human dignity. See Jaftha $v$ Schoeman and Others, Van Rooyen v Stoltz and Others 2005 (2) SA 140 (CC), at paras 20-21; Port Elizabeth Municipality v Various Occupiers (CCT 53/03) [2004] ZACC 7 at 17-18. 
constitutional right to housing in South Africa is justified exclusively on the basis that it promotes positive liberty. South African courts have also explored the right to housing's role in protecting negative liberty, especially in the context of forced evictions and reducing their negative consequences. ${ }^{40}$

Along the same vein, the Supreme Court of India has also highlighted the connection between positive liberty and access to housing in a series of decisions. India's Constitution does not expressly guarantee a right to housing. Rather, it distinguishes between enforceable fundamental rights, such as the right to life, and Directive Principles of State Policy, which the state should aspire to fulfil but which are not judicially enforceable, such as the entitlement to a decent standard of living. ${ }^{41}$ Although the provision of a decent standard of living is constitutionally classified as a non-enforceable Directive Principle of State Policy, the Supreme Court of India has nonetheless ruled that a right to housing is encompassed within the judicially enforceable fundamental right to life. ${ }^{42}$ This has led to the de facto recognition of a constitutional right to housing. ${ }^{43}$

Similar to the Constitutional Court of South Africa, the Supreme Court of India has drawn a connection between access to housing and the promotion of dignity and self-actualization. ${ }^{44}$ As the Supreme Court of India explained, housing promotes flourishing and "a bare minimum expression of the human self." ${ }^{45}$ For instance, in the Chameli Singh decision, the Court observed:

In any organised society, right to live as a human being is not ensured by meeting only the animal needs of man. It is secured only when he is assured of all facilities to develop himself and is freed from restrictions which inhibit his growth. All human rights are designed to achieve this object. [...] Shelter for a human being, therefore, is not a mere protection of his life and limb. It is home where he has opportunities to grow physically, mentally, intellectually and spiritually. [...] The right to shelter, therefore, does not mean a mere right to a roof over one's head but right to all the infrastructure necessary to enable them to live and develop as a human being. ${ }^{46}$

The Supreme Court of India has suggested that the right to life includes the right to livelihood and development of one's personality, both of which are promoted through access to housing. ${ }^{47}$ And the High Court of Delhi has remarked that "adequate housing serves as the crucible for human well-being and development." 48

The International Covenant on Economic, Social, and Cultural Rights also alludes to an important relationship between access to housing and positive freedom. ${ }^{49}$ For example, General Comment No. 4:

40 See e.g. City of Johannesburg $v$ Changing Tides 74 (Pty) Ltd and Others (SCA) [2012] ZASCA 116; Occupiers of Mooiplaats $v$ Golden Thread Ltd \& Others 2012 (2) SA 337 (CC); Port Elizabeth Municipality, ibid at paras 17-18.

41 Hohmann, supra note 5 at 108-09; India Constitution (1950), s 21(a) [right to education], s 37 [non-enforceability of directive principles], and s 43 [provision of a decent standard of living].

42 Hohmann, ibid at 110-11.

43 Ibid.

44 Ibid; Francis Coralie Mullin v The Administrator, Union Territory of Delhi \& ORS (1981) AIR 746, 1981 SCR (2) 516, [Mullin] at para 5. Cited in Hohmann, ibid.

45 Mullin, ibid.

46 Chameli Singh vs State Of U.P (1996) 2 SCC 549, at para 8.

47 Ahmedabad Municipal Corporation v Nawab Khan Gulab Khan AIR (1997) SC 152.

48 Sudama Singh \& Others v Government of Delhi \& Anr, WP(C) 8904/2009 (11 February, 2010) (High Court of Delhi) at para 26.

49 UN General Assembly, International Covenant on Economic, Social and Cultural Rights, 16 December 1966, United Nations, Treaty Series, vol. 993 [ICESCR] at 3. 
The Right to Adequate Housing remarks that housing is the bedrock for enjoying all other economic, social, and cultural rights - the types of rights that are characteristically tied to increasing one's selffulfillment by benefiting from a minimal standard of living. ${ }^{50}$ This bedrock function also explains why the right to housing is often conceptualized as an economic or social right. ${ }^{51}$

There is therefore a connection between a lack access to housing and the reduction of positive freedom. The physical structure of a home provides a degree of security, autonomy, privacy, and predictability in a person's life, and those values are connected to self-actualization, personhood, and authenticity, all of which are intrinsic to positive freedom. ${ }^{52}$ Without access to housing, individuals lose a crucial instrument for protecting those values and, ultimately, lack a vital means to self-actualize.

\section{NEGATIVE LIBERTY AND ACCESS TO HOUSING}

\section{A. Negative Liberty}

Whereas positive liberty is framed in terms of the freedom to be and the freedom act in ways that are consistent with human flourishing and self-government, negative liberty is concerned with freedom from obstructions or impediments by others. ${ }^{53}$ The notion of negative liberty, therefore, takes freedom as one's sphere of unobstructed choice - a person is free to the extent that nobody concretely interferes with their actions. $^{54}$

In Anglo-American law, civil and political rights tend to be negative in nature, meaning that individuals' rights are protected against interferences by the state. ${ }^{55}$ In many respects, this tendency stems from historical concerns about limiting government's power over the individual and countering the prospect of tyranny. ${ }^{56}$ Certain negative freedom theorists are also preoccupied with state attempts to maximize positive liberty, because positive liberty can be associated with authoritarian and totalitarian rule. ${ }^{57}$ According to Berlin, positive liberty — or whatever the state dictates it to be — is pursued over individual conceptions and pursuits of freedom deemed contrary to that goal. ${ }^{58}$ And history shows that in the face of totalitarian governments, the individual's conception of freedom yields to that of the state, ultimately resulting in harsh repression. ${ }^{59}$

50 UN Committee on Economic, Social and Cultural Rights (CESCR), General Comment No 4: The Right to Adequate Housing (Art. 11 (1) of the Covenant), 13 December 1991, E/1992/23 [CESCR, Comment: Housing].

51 See e.g. Cass Sunstein, "Social and Economic Rights? Lessons from South Africa (1999-2001) 11 Const F 123; Natasha G Menell, "Judicial Enforcement of Socioeconomic Rights: A Comparison Between Transformative Projects in India and South Africa” (2016) 49 Cornell Int LJ 723.

52 Radin, supra note 3 at 991-92.

53 Berlin, supra note 9 at 122.

54 Ibid; Gray, supra note 10 at. 512.

55 Abraham, supra note 27 at 63.

56 See e.g. James E Fleming \& Linda C McClain, "Liberty" in Tushnet, Graber, and Levinson, eds, The Oxford Handbook of the U.S. Constitution (Oxford: Oxford University Press, 2015) at 480-81; Gordon S Wood, The Creation of the American Republic, 1776-1787 (Chapel Hill: University of North Carolina Press, 1998) at 271-72; Leonard Levy, Origins of the Bill of Rights (New Haven: Yale University Press, 2001) at 21, 33; Rv Big M Drug Mart Ltd., [1985] 1 SCR 295 at para 95.

57 Mark Tushnet, "Essay on Rights” (1984) 62 Tex L Rev 1363 at 1392; Berlin, supra note 9 at 144; Sandra Fredman, Human Rights Transformed: Positive Rights and Positive Duties (Oxford: Oxford University Press, 2008) at 20.

58 Tushnet, ibid at 1392; George Crowder, Liberalism and Value Pluralism (London: Continuum, 2002) at 85. Hayek advances a similar concern when discussing the dangers of extreme forms of centralized planning. See Friedrich A Hayek, The Road to Serfdom: Text and Documents: The Definitive Edition (New York: Routledge, 2014$)$ at $217-8$. 
Outside of overarching political theory considerations, there are significant differences between negative and positive liberty as the metrics for evaluating the extent of one's freedom. Negative rights and negative liberty tend to be more determinate and less abstract than positive rights and positive liberty. Conceptually, it can be easier to ascribe certain interferences with one's negative freedom to another's conduct, compared to ascribing certain failures to actualize positive freedom to another's conduct. Restrictions of negative freedom also tend to be more clearly causally attributable to others' actions compared to omissions to fulfil a positive right and maximize positive liberty. ${ }^{60}$

\section{B. Access to Housing and Protection Against Interference}

Access to housing is often associated with the negative conception of liberty for a variety of reasons. Housing affords individuals with some of the strongest legal protections against unwanted intrusions by the state and by other private individuals. ${ }^{61}$ The police require warrants to enter and search dwelling houses save for in exigent circumstances. ${ }^{62}$ In Canada, the wider areas surrounding one's home, such as one's yard and shed, are protected against perimeter searches by the police, unless the police obtain the owner's permission or judicial authorization. ${ }^{63}$ The home's physical structure also protects one's belongings and stands as a barrier against plain-view searches. And in the realm of property law, having access to housing endows individuals with the private power to exclude others - a power that is backed by police enforcement of that right. ${ }^{64}$ Without access to housing, people lose many of those legal protections.

In the international context, the right to housing is also framed in terms of its capacity to safeguard negative liberty, including by providing security of tenure, protecting against eviction, and ensuring just compensation for takings. ${ }^{65}$ Some scholars therefore point out that, despite the absence of a formal constitutional right to housing in Canada and the United States, a range of narrow statutory measures aim to secure one's negative liberty by maximizing access to housing. ${ }^{66}$ Those measures include substantive and procedural safeguards against eviction, a right to be free from discrimination in the allocation of housing, and building codes, amongst others. ${ }^{67}$ Some scholars also point to legal rules and policies that aim to promote negative freedom by deterring displacement as a result of gentrification, including through zoning laws and Environmental Impact Statements. ${ }^{68}$ And lastly, some allude to statutory schemes that prevent the types of predatory lending practices that lead to home foreclosures. ${ }^{69}$

60 Tony Honore, Responsibility and Fault (Oxford: Bloomsbury 1999) at 52-53; Mario Ricciardi, "Liberty" in Besussi, ed, A Companion to Political Philosophy. Methods, Tools, Topics (Abingdon: Routledge, 2012) at 154; George Fletcher, "Omissions: Some Perspectives" (1976) 24 Am J Compar L 703 at 706; Arthur Leavens, "A Causation Approach to Criminal Omissions" (1988) 76 Cal L Rev 547 at 572. As Leavens points out, however, there are certain cases where omissions can be said to be causally linked to certain consequences, ibid at 562-63.

61 Barros, supra note 1 at 263-64.

62 See supra notes 6 and 7.

$63 \quad R$ v Kokesch, [1990] 3 SCR 3.

${ }_{64}$ Cohen, supra note 8 at 12.

65 CESCR, Comment: Housing, supra note 50, s. 8(a); U.N. Office of the United Nations High Commissioner for Human Rights, The Right to Adequate Housing, Fact Sheet No. 21/Rev. 1 (Geneva) at 3-4.

66 Shelby D Green, "Imagining a Right to Housing, Lying in the Interstices" (2012) 19 Geo J on Poverty L \& Pol'y 393 at 439.

67 Ibid.

68 Hannah Weinstein, "Fighting for a Place Called Home: Litigation Strategies for Challenging Gentrification" (2015) 62 UCLA L. Rev. 794 at 810-11.

69 Daniel Chatlos, "Grabbing the Bull by the Horns: The Future of Mortgage Lending and Securitization in the Aftermath of the Financial Crisis" (2014) 25 U Fla JL \& Pub. Pol'y 137 at 162. 
Negative freedom theory also aptly captures how laws that regulate public property limit the freedom of people without access to housing in ways that positive liberty theory does not. Public property connotes open-access spaces that are managed by the state, where individuals lack a private power to exclude others. ${ }^{70}$ Waldron's influential essay "Homelessness and the Issue of Freedom" famously illustrated why homeless people lack negative freedom. ${ }^{71}$ In his view, homeless people's negative unfreedom stems from the cumulative effect of property law rules and ordinances governing the use of public property. ${ }^{72}$

As he describes, laws that regulate public property prohibit public displays of basic human acts that everyone must engage in, including sleeping, urinating, and sitting on public property. ${ }^{73}$ Yet if the state prohibits public displays of those basic human acts, and homeless people do not have a private place to perform those acts because they lack access to housing, homeless people lose the negative freedom to engage in the most rudimentary human conduct. ${ }^{74}$ Notably, laws that govern public property undermine homeless people's negative freedom to alleviate their needs in public. And if homeless people wish to do those acts in private, homeless people require permission from others to use their private property and perform those acts. ${ }^{75}$ Therefore, there are few places where homeless people are negatively free to perform their basic human acts. ${ }^{76}$

Waldron's account captures how housing protects negative freedom in ways that positive liberty theorists might ignore. Surely, a person lacks positive freedom if they do not have access to housing, must sleep in public, and must unwillingly expose themselves to others. ${ }^{77}$ As Waldron's argument makes clear, that indignity is made even worse when a homeless person is then ticketed, arrested, or punished by the state for having nowhere else to alleviate their needs but on public property. ${ }^{78}$ This constitutes a form of state-sanctioned insult to injury that the person would otherwise not have experienced. As Waldron sums up, "though we say there is nothing particularly dignified about sleeping or urinating, there is certainly something deeply and inherently undignified about being prevented from doing so.",79

\section{Access to Housing and Negative Liberty: Some Limitations}

By building on Waldron's crucial account and highlighting certain considerations that fall outside the scope of his argument, it is possible to develop a more well-rounded understanding of the importance of access to housing when the state regulates public property. First, when individuals lack access to housing, they can still be unfree even if they do not experience concrete interference by others. ${ }^{80}$ Conceptualizing freedom as non-interference ignores how a person may restrict their own liberty to prevent interference,

70 Michael Robertson, "Public Property Redux" (2016) 49 UBC L Rev 563 at 608.

71 Jeremy Waldron, "Homelessness and the Issue of Freedom” (1991-1992) 39 UCLA L. Rev. 295.

72 Ibid; Bernard Harcourt, "Reflecting on the Subject: A Critique of the Social Influence Conception of Deterrence, the Broken Windows Theory, and Order-Maintenance Policing New York Style” (1998) 97 Michigan L Rev 291 at 301 ; Christine Bella \& David Lopez, "Quality of Life--At What Price? Constitutional Challenges to Laws Adversely Impacting the Homeless" (1994) $10 \mathrm{~J}$ of Civ Rts \& Econ Dev 89 at 91-93.

73 For an overview of those laws in the U.S and Canada, see note 22, supra.

74 Waldron, "Homelessness and the Issue of Freedom", supra note 71, p. 302.

75 Ibid at 304.

76 Ibid, at 296, 302.

77 Ruth Gavison, "Privacy and the Limits of the Law" (1980) 89 Yale LJ 421 at 455.

78 Waldron, "Homelessness and the Issue of Freedom", supra note 71, p. 320.

79 Ibid.

80 Pettit, Republicanism, supra note 14 at 63-64. 
by ensuring that others do not frustrate that person's plans or actions. ${ }^{81}$ In later reflections about his previous work, Berlin conceded that the concept of negative freedom generated that dilemma. ${ }^{82}$ As Pettit puts it, freedom as non-interference suggests that people can secure their freedom by changing their preferences, living inauthentically, and tailoring their plans to others' wishes as a coping mechanism to avoid interference. ${ }^{83}$

For instance, suppose that to benefit from the same degree of freedom as people with access to housing, a person experiencing homelessness adopts strategies to alleviate their basic needs without interference by others. Perhaps they move to a secluded part of the city where their likelihood of experiencing police coercion significantly decreases. ${ }^{84}$ Additionally, in relative isolation, they can perform their most basic human acts without having to seek others' permission to use their private property. ${ }^{85}$ In those circumstances, those experiencing homelessness may benefit from a similar degree of non-interference as people with access to housing when alleviating their basic needs. But it is disingenuous to assert that the individuals without access to housing therefore benefit from a similar degree of liberty. Notably, achieving non-interference comes at the price of the individual excluding themselves from the community, abandoning their true desires, and making trade-offs that nobody should have to make in order to claim that they are free. ${ }^{86}$

Second, the negative conception of liberty can ignore the wider problem of dependency, as well as the connection between unstable access to housing and a lack of independence in a person's life. ${ }^{87}$ To illustrate this problem, it is important to think about the predicament faced by the precariously housed, provisionally accommodated, and hidden homeless population. ${ }^{88}$ This includes individuals who are, for all intents and purposes, experiencing homelessness but for the graciousness of a friend, acquaintance, or family member who allows them to stay on their private property. ${ }^{89}$

Essert has recently argued that the fundamental purpose of private property is that it prevents the dependency on others that results from a lack of access to housing. "Although the terms "dependence" or "dependency" have different meanings that have evolved over time, their common root is that they are each intimately linked to a notion of subordination. ${ }^{91}$ As Essert points out, access to housing provides individuals with free and unrestricted access to a private place where they can stay without doing so at

81 Ibid; Isaiah Berlin \& Henry Hardy, Freedom (Oxford: Oxford University Press, 2012) at 30-32; Pettit, On the People's Terms, supra note 14 at 64; Philip Pettit, "Discourse Theory and Republican Freedom" in Christian Nadeau \& Daniel Weinstock, eds, Republicanism: History, Theory, Practice (Abingdon: Routledge, 2004) at 77.

82 Ibid.

83 Pettit, On the People's Terms, supra note 14 at 64; For an interesting and similar account of this argument in the discrimination context, see notably: Kenji Yoshino, "Covering" (2002) 111 Yale LJ 759 at 772.

84 See e.g. Kimberly Bender et al, "Capacity for Survival: Exploring Strengths of Homeless Street Youth" (2007) 26 Child Youth Care Forum 25 at 35; This argument was advanced in: Skolnik, "Regulated Differently", supra note 21 at 314.

85 Ibid.

86 Ibid. See Charles Taylor, "Cross-Purposes: The Liberal-Communitarian Debate" in Derek Matravers \& Jonathan Pike, eds, Debates in Contemporary Political Philosophy (New York: Routledge, 2003) at 198. Though addressing a different point, see the concerns advanced by Jeremy Waldron, "Community and Property — For Those Who Have Neither" (2009) 10 Theor Inq L 161 at 169.

87 Essert, supra note 24.

88 Gaetz, Gulliver \& Richter, supra note 18 at 39.

89 See e.g. Latimer et al., "I Count MTL 2015: Count and Survey of Montreal's Homeless Population on March 24, 2015" online: City of Montreal $<$ http://ville.montreal.qc.ca/pls/portal/docs/page/d_social_fr/media/documents/I_Count_MTL_2015_report.pdf >; John Howard Society, "Homeless and Jailed: Jailed and Homeless" (Toronto: 2010$)$ at 8.

90 Essert, supra note 24 at 266.

91 Nancy Fraser \& Lisa Gordon, “A Genealogy of Dependency: Tracing A Keyword in the U.S. Welfare State” (1994) 19 Signs 309 at 331. 
someone else's pleasure and without being subordinated to others' private power of exclusion. ${ }^{92}$ The crucial point, is that access to housing also endows people with the freedom to perform an infinite array of actions within their homes without having to be granted permission by others. ${ }^{93}$ Thus, housing protects individuals against the vulnerability of constantly being excluded by others and being unfree to perform many actions. 94

Those who are precariously housed with friends, acquaintances, or family, and those staying at a homeless shelter, all experience that vulnerability. ${ }^{95}$ Any mindful guest who has inched towards overstaying their welcome is aware of that feeling. The guest may internalize the fact that they can be excluded by their host and respond in various ways. ${ }^{96}$ They may be deferential to get on their host's good side. ${ }^{97}$ Or, the guest may tolerate whatever verbal abuse the host directs towards them, as long as it keeps a roof over the guest's head. The guest may mould their own behaviour around trying to guess their host's expectations and ingratiate themselves as a means of receiving better treatment or prolonging their stay. ${ }^{98}$ The relationship of subordination can therefore discredit any claim that the precariously housed homeless person is meaningfully free. The dynamics of the relationship described above, suggest that the guest's presence and liberty to act are the product of their host's tolerance, as opposed to the guest's own freedom. Indeed, to experience homelessness is to be a guest in a world of hosts, where one's freedom depends on others' benevolence and good will. The problem with thinking about access to housing by appealing to negative freedom theory, is that it can ignore the problem of subordination, as long as that subordination does not result in concrete interference. ${ }^{99}$

\section{REPUBLICAN LIBERTY AND ACCESS TO HOUSING}

\section{A. Republican Liberty}

There is a third conception of liberty that provides new insight into the relationship between access to housing and freedom, which is especially relevant in contexts where the state regulates public property. Republicanism, or the republican conception of freedom, dates back to the era of the Roman Republic and differs from both positive and negative theories of liberty in important respects. ${ }^{100}$ While negative freedom theory conceptualizes liberty as non-interference, republicanism construes liberty as non-domination. ${ }^{101}$ Non-domination implies that others lack the unilateral power or capacity to interfere with an individual's life and actions. ${ }^{102}$ Thus, non-domination implies a form of secured negative liberty. ${ }^{103}$

92 Essert, supra note 24 at 288.

93 Ibid at 276.

94 Jane Baron, "Homelessness as a Property Problem” (2004) 36 Urban Lawyer 273 at 287; Jane Baron, "Property and No Property" (2006) 42 Houston L Rev 1425 at 1438, 1443-44; Jane Baron, "Rescuing the Bundle-of-Rights Metaphor in Property Law" (2013) 82 U Cin L Rev 57 at 92. On the relationship between access to housing and subordination, see: Margot Young, "Charter Eviction: Litigating Out of House and Home” (2015) 24 J L \& Soc Pol'y 46 at 54.

95 Essert, supra note 24 at 274.

96 Pettit, Republicanism, supra note 14 at 60; Pettit, On the People's Terms, supra note 14 at 64 . Those mechanisms are all discussed by Pettit, although not in a context relating to access to housing (notes 113-5, infra).

97 Pettit, On the People's Terms, ibid.

98 Ibid; Spector, supra note 30 at 798.

99 Pettit, Republicanism, supra note 14 at 63-64. See notably Pettit's discussion on the benevolent master.

100 Ibid, Ch 1 [exploring the distinction between negative liberty, positive liberty, and republicanism].

101 Ibid at 52-53; Philip Pettit, "On the People's Terms: A Reply to Five Critiques" (2015) 18 Crit Rev Int Soc \& Pol Phil 687 at 687.

102 Philip Pettit, "Law and Liberty" in Besson \& Martí, eds, Law and Republicanism (Oxford: Oxford University Press, 2009) 44 [Pettit, "Law and Liberty"].

103 Tarunabh Khaitan, A Theory of Discrimination Law (Oxford: Oxford University Press, 2015) at 98-99. 
In the republican tradition, domination is often elucidated by reference to the subordinating relationship between master and slave, in which the former unilaterally wields power over the latter. ${ }^{104}$ As Pettit argues, domination can arise in a variety of contexts and relationships, such as the abusive spouse who unilaterally wields power over their partner and the employer who possesses the capacity to fire their employees at will. ${ }^{105}$ To republicans, the mere fact that one individual possesses the capacity to unilaterally interfere with another is morally problematic, irrespective of whether actual interference occurs. Republicans refer to that state of affairs as "domination without interference."106

The concept of domination without interference addresses certain limitations to negative liberty theory. First, domination without interference recognizes that individuals who limit their own freedom to avoid interference are not truly free, because they are still unilaterally subject to others' will and are subject to domination. ${ }^{107}$ Second, because negative freedom is concerned with actual interferences with a person's actions, it offers a binary conception of whether that person is at liberty to go somewhere or do something. ${ }^{108}$ Republicanism offers a more nuanced account of liberty. It recognizes that the threat of interference can vary according to different factors, such as intensity, frequency, and consistency. ${ }^{109}$ Moreover, domination can occur in some places but not others. ${ }^{110}$ Thus, republicanism construes both liberty and domination across a spectrum, without categorizing their respective existence as either absent or present. And finally, bridging a gap with positive liberty, the republican theory of freedom acknowledges that domination undermines opportunities to self-actualize, if individuals must act knowing that their courses of action are susceptible to being frustrated by others. ${ }^{111}$

\section{B. The Regulation of Public Property and Domination}

Against that backdrop, it is possible to consider a deeper relationship between access to housing and republican freedom. Some scholars observe that a crucial aspect of lacking access to housing is that individuals become increasingly vulnerable to others' power and are subject to domination. ${ }^{112}$ In such circumstances, others can exclude those individuals at will, and in doing so, obstruct those individuals from engaging in a range of actions on others' property. ${ }^{113}$ Baron and Essert's accounts focus primarily on the private property regime, and how the exclusion of certain individuals from that regime perpetuates asymmetrical power dynamics in society. Their accounts, however, are not generally concerned with how the regulation of public property subjects those without access to housing to domination, a problem that is discussed next.

To illustrate why laws that regulate public property can result in domination, it is first necessary to understand the more general justifications for the state regulating public property - justifications that have

104 Fabian Wendt, "Slaves, Prisoners, and Republican Freedom" (2011) 17 Res Publica 175 at 179 [describing the relationship between slave and master as normative as opposed to merely descriptive]; Quentin Skinner, Liberty Before Liberalism (Cambridge: Cambridge University Press, 1998) at 70. Pettit, Republicanism, supra note 14 at 58.

106 Ibid at 63-64; Philip Pettit, "Keeping Freedom Simple: On a Difference with Quentin Skinner" (2002) 30 Political Theory 339 at 345.

107 Pettit, On the People's Terms, supra note 14 at 64.

108 Skolnik, "Regulated Differently", supra note 21.

109 Pettit, Republicanism, supra note 14 at 58.

110 Ibid.

111 On a connection between positive liberty and republicanism, see Charles Larmore, "Liberal and Republican Conceptions of Freedom" in Nadeau \& Weinstock, supra note 81 at 86-7 especially.

112 Baron, supra note 94; Essert, supra note 24 at 274.

113 Essert, ibid. 
been accepted by Canadian and U.S. courts in the context of constitutional litigation. ${ }^{114}$ Laws that regulate spaces such as public parks, beaches, streets, and sidewalks are enacted on the basis of different justifications. Those justifications include promoting public welfare, security, sanitation, aesthetics, and public efficiency, as well as for economic rationales and to solve coordination problems. ${ }^{115}$ Those objectives traditionally fall within a state's police power, meaning its authority to enact laws for the public welfare or common good. ${ }^{116}$

Courts have ruled that the state's police power justifies the regulation of sidewalks and streets to promote efficiency. ${ }^{117}$ Courts have held that the state's police power justifies banning camping in parks as a means to promote their aesthetic value, public attractiveness, and communal use. ${ }^{118}$ And to protect public health, the police power justifies proscribing public urination and defecation. ${ }^{119}$ Indeed, because so many different people with shared and conflicting interests must co-exist on public property, the police power is used to settle those disagreements through laws that dictate the appropriate norms of public conduct and use of public space.

But there is a more general reason why courts have found that the state is justified in enacting those laws by virtue of their police power. Because public property functions as an open-access space that derives its value from its publicness, and because public property occupies a collective function by being shared by the entire community, the state is justified in enacting laws that protect public property's unique social role. ${ }^{120}$ Public property also fulfills important democratic, communal, and social functions within society. ${ }^{121}$ As Rose explains, public property's open-access nature enhances sociability and cohesion. ${ }^{122}$ Those spaces allow people from all walks of life to spontaneously gather together, protest, play, relax, and pursue individual and shared projects - individuals learn to live together despite their differences. ${ }^{123}$ As she points out, the more people that participate in those activities, the greater the benefit of public property for everyone. ${ }^{124}$

But because public property is an open-access space, it is also subject to a "tragedy of the commons," where each individual's attempt to maximize their use of public property undermines its collective value for others. ${ }^{125}$ Hardin observed that a system of mutual coercion is necessary to avoid a tragedy of the

114 This argument, and the arguments advanced in this subsection and the next subsection, were first advanced in Skolnik, "Regulated Differently", supra note 21 at 304.

115 Skolnik, ibid; See e.g. Maria Foscarinis, Kelly Cunningham-Bowers \& Kristen E Brown, "Out of Sight - Out of Mind: The Continuing Trend toward the Criminalization of Homelessness" (1999) 6 Geo. J Poverty L \& Pol'y 146 at 152-56; Clark v Community for Creative Non-Violence, 468 US 288 (1984) at 296; Victoria (City) v Adams, 2008 BCSC 1363 at para 173; Abbotsford (City) v Shantz, 2015 BCSC 1909 at paras 19-20.

116 Harry N Scheiber, "Public Rights and the Rule of Law in American Legal History" (1984) 72 Cal L Rev 217 at 221 ; Larissa Katz, "Governing Through Owners: How and Why Formal Private Property Rights Enhance State Power" (20112012) 160 U Pa L Rev 2029 at 2047.

117 See e.g. Roulette v City of Seattle, 97 F. 3d 300 (9th Circ, 1996) at 308.

118 See e.g. Victoria (City) v Adams, BCCA 563, at paras 119-20; Tobe v City of Santa Ana, 892 P 2 d 1145 (Cal: Supreme Court, 1995) at 1109 .

119 Foscarinis, Cunningham-Bowers \& Brown, supra note 115 at 152-53.

120 Carol Rose, "The Comedy of the Commons: Custom, Commerce, and Inherently Public Property" (1986) 53 U Chicago L Rev 711 at 774-75; Skolnik, "Regulated Differently", supra note 21 at 303-4.

121 Skolnik, ibid; Nadav Shoked, “The Duty to Maintain” (2014) 64 Duke LJ 437 at 451-52. See also Robertson's analysis of C.B. MacPherson's view on the role of public property in: Robertson, supra note 70 at 581.

122 Rose, "The Comedy of the Commons", supra note 120, p. 723.

123 Id, p. 768.

124 Ibid.

125 Garrett Hardin, "The Tragedy of the Commons" (1968) 162 Science 1243, p. 1244; Skolnik, "Regulated Differently", supra note 21. 
commons - a position that has since been challenged by many scholars. ${ }^{126}$ Laws that govern public property and the institution of private property both function as systems of mutual coercion to achieve that end. ${ }^{127}$

By understanding both laws that regulate public property and private property as systems of mutual coercion that reduce the likelihood of a tragedy of the commons, it is possible to grasp how lacking access to housing results in domination and undermines individual freedom. Notably, people with access to housing are meaningfully protected against the state regulating and policing their most basic human acts, whereas people without access to housing are not. ${ }^{128}$ Homeless people therefore experience a distinct form of domination. ${ }^{129}$ And as will be explained next, that domination exists because the state can more justifiably regulate basic human acts on public property than on private property. ${ }^{130}$

Recall that to optimize public property's democratic value, promote its communal use, maintain its attractiveness, and to reduce the likelihood of a tragedy of the commons, the state can ban acts such as sleeping, camping, nudity, sexual intercourse, urination, and defecation on public property. ${ }^{131}$ But homes are not open-access spaces. They do not fulfil some type of communal and democratic function. And they are not prone to a tragedy of the commons because they are not open-access spaces. Those realities account for why the state often has greater justifications for regulating basic human acts that occur on public property to promote its shared use for the entire community, instead of regulating those same acts within the privacy of one's home. Because the home is not an open-access space, the reasons for regulating certain acts on public property could not justify regulating those same acts on private property. ${ }^{132}$ To illustrate that point, consider how many cities regulate sleeping or camping on public property, and how few (if any) cities intrusively regulate and police how people do those same acts in the privacy of their homes.

Another reason why the state is often less justified in policing how people alleviate their needs within the privacy of their homes derives from the strong legal protections and expectation of privacy that a home confers. ${ }^{133}$ A law giving the state license to police how people sleep or urinate within their homes would be so intrusive to privacy that it would likely be declared unconstitutional in any liberal and democratic society. ${ }^{134}$ For one, it would be difficult for the state to justify that the state's objectives outweigh the intrusive impact on individuals' dignity and privacy. ${ }^{135}$ Moreover, it is hard to imagine that the state would

126 Ibid. Several scholars have challenged the concept of a tragedy of the commons as well as its inevitability on common property. See: Surabhi Ranganathan, "Global Commons" (2016) EJIL 27 693. See a summary of the challenges to Hardin's claim regarding the potential of common property to "self-destruct" if left unregulated, in: Robertson, supra note, 70 , pp. 569 and $\mathrm{f}$.

127 Ibid. On private property as a system of mutual coercion, see Lee-Anne Fennell, “Adjusting Alienability” (2009) 122 Harv L Rev 1403 at 1430. On laws governing public property as a system of mutual coercion, see Robert Ellickson, "Controlling Chronic Misconduct in City Spaces: Of Panhandlers, Skid Rows, and Public-Space Zoning" (1996) 105 Yale LJ 1165 at 1168-69.

128 Skolnik, "Regulated Differently", supra note 21 at 319-20.

129 Ibid.

130 Ibid.

131 Ibid at 303-4.

132 Ibid, at 319-20. Furthermore, many of those acts are entirely morally acceptable in private and only become objectionable or indecent when others are unwillingly exposed to them, which undermines any need for regulation on the basis of offense to others (ibid). See e.g. John Stuart Mill, On Liberty, 2nd ed (Boston: Ticknor and Fields, 1863), at 189190; Andrew Simester and Andrew von Hirsch, "Rethinking the Offence Principle" (2002) 8 Legal Theory 269, p. 275. 
be unable to achieve its goals in a manner that is less demeaning of individual privacy and dignity. Admittedly, there are some exceptions to the principle that the state is more justified in regulating certain need-alleviating acts on public property compared to on private property, such as the state's power to declare an unsanitary home unfit for habitation. ${ }^{136}$ The state, however, still generally has a broader power to police how people perform their most basic acts on public property.

The republican theory of freedom illustrates why, as systems of mutual coercion, the private property regime and the regulation of public property together produce significant injustices for homeless people. By being excluded from the private property regime, people without access to housing tend to only exist as guests on others' private property. And for homeless people who live on public property because they have nowhere else to go, they lack the quintessential means to shield themselves from the state policing their most basic acts. ${ }^{137}$ Where the state regulates public property, to experience homelessness is to be subject to domination by the state and by other individuals.

\section{Republicanism and Access to Housing: Concrete Implications}

Those considerations explain why the state possesses a far greater power to regulate and police how a person sleeps, urinates, defecates, sits, or lies down when they lack access to housing. ${ }^{138}$ Indeed, when a person does not have access to housing and the state regulates public property, four major consequences result, which republicanism helps reveal. First, a person's opportunities to obey laws that govern public property are increasingly delegated to others. ${ }^{139}$ Access to housing therefore protects against a certain form of domination: becoming dependent on others to obey laws that regulate public property and avoid coercion by the police. An array of routine interactions exemplifies that domination. When a homeless person asks a coffee shop employee to use the shop's bathroom in order to obey a rule banning public urination, there is domination because that permission is unilaterally subject to the employee's will. ${ }^{140}$ And domination is often present when a homeless person, in an attempt to comply with an ordinance that prohibits camping in public, submits to a homeless shelter's restrictive rules, conditions, and policies in order to stay there overnight. ${ }^{141}$

Second, without access to housing, the justifications for laws that govern public property operate much like a self-fulfilling prophecy resulting in domination. If there are few private places where homeless people can freely alleviate their needs, homeless people will generally engage in the very acts that justify the regulation of public property in the first place. For example, without a private place to alleviate their needs, homeless people will inevitably urinate, defecate, or sleep on public property. This, in turn, can generate public sanitation concerns, result in coordination problems, discourage the use of certain public spaces, and undermine the efficiency of public rights of way. ${ }^{142}$ When a person lacks access to housing, their most basic acts will increasingly invite a risk of interference to which they would otherwise not be exposed — the state has greater power over their life, their body, and their basic actions.

136 Ibid at 321; See e.g. Public Health Act, RSA 2000, c P-37, s. 62(1)(b); Health Act, RSBC 1996, c 179, s 63(4)(b); Daniel R Mandelker, "Housing Codes, Building Demolition, and Just Compensation: A Rationale for the Exercise of Public

Powers over Slum Housing” (1969) 67 Mich L Rev 635 at 642-43. This example also cited in Skolnik, ibid.

137 Skolnik, ibid at 319-20.

138 Ibid.

139 Ibid at 310.

140 Ibid, at 315.

141 Essert, supra note 24 at 274.

142 For example, see: Gary Blasi, "Policing Our Way Out of Homelessness? The First Year of the Safer Cities Initiative on Skid Row" (Los Angeles: UCLA School of Law Fact Investigation Clinic, 2007) at 26 [sanitation concerns]; Joyce v City and County of San Francisco, 846 F Supp 843 (Dist Court, ND California, 1994) at 846 [economic concerns]. 
Third, without access to housing, individuals must often limit their own liberty to avoid interference. Individuals experiencing homelessness are frequently placed in situations where they must trade off their most basic interests to secure their freedom from certain types of obstructions. ${ }^{143}$ Consider the price that homeless people must pay to comply with laws that govern public property. Often, to escape fines and arrests for violating those laws, homeless people must risk their physical safety, health, or property in homeless shelters. ${ }^{144}$

Lastly, individuals without access to housing also lack a sense of predictability and certainty in their lives, because others have the capacity to interfere with their actions and plans. ${ }^{145}$ They lose the peace of mind that comes from feeling and knowing that one is free. ${ }^{146}$ People experiencing homelessness do not know when they will be asked to leave another's private property or be obstructed from freely performing some action. They are unsure whether they will be allowed to use someone's property to obey some law governing public property. When going to sleep in a subway station or on a park bench, they close their eyes with the knowledge that the police may wake them and order them to move elsewhere. To lack access to housing is to live with a heightened sense of vigilance and a subjective awareness that one can be interfered with at any moment by others. ${ }^{147}$ Indeed, without access to housing, an individual lacks a crucial means to live independently and on their own terms; they lack one of the most significant tools for protecting themselves against domination. ${ }^{148}$

\section{CONCLUSION}

This article argued that our prevailing understanding of the relationship between access to housing and liberty is limited, because scholars and courts tend to examine the importance of access to housing uniquely through the lenses of negative and positive liberty. Analyzing the importance of access to housing through the combined lenses of positive, negative, and republican liberty, however, provides a more wellrounded understanding of how housing protects individual freedom.

This article argued that by also exploring the importance of access to housing from the perspective of republicanism, we gain the following insights into how housing protects individual liberty. For one, when the state regulates public property, individuals with access to housing are afforded important protection against the state policing their most basic human acts. ${ }^{149}$ Second, when an individual has access to housing, that individual's opportunities to freely obey laws that govern public property are placed within their own control, as opposed to being delegated to others. ${ }^{150}$ Third, although the state can justifiably implement systems of mutual coercion to prevent a tragedy of the commons on public property, republicanism illustrates why certain systems of mutual coercion undermine the liberty of people without access to housing and produce injustices. Notably, laws that manage public property can operate like a self-fulfilling prophecy against those without access to housing. Since people without access to housing are at the greatest risk of alleviating their needs on public property, such conduct in turn justifies the state's management of public property through coercion.

143 Skolnik, "Regulated Differently", supra note 21 at 317.

144 Ibid.

145 Pettit, Republicanism, supra note 14 at 85.

146 Terry Skolnik, "Homelessness and the Impossibility to Obey the Law" (2016) 43 Fordham Urb LJ 741 at 745.

147 Pettit, On the People's Terms, supra note 14 at 61; Pettit, "Law and Liberty", supra note 102 at 44; Skolnik, "Regulated Differently", supra note 21 at 3

148 Essert, "Property and Homelessness", supra note 24 at 266-67.

149 Ibid; Skolnik, "Regulated Differently", supra note 21 at 319-20.

150 Ibid at 310. 
By unifying the respective insights of the three conceptions of liberty, this article demonstrates the ever-pressing need for the state to ensure that people have access to adequate housing. Notably, access to housing fosters positive liberty, by promoting self-actualization, privacy, dignity, security, and autonomy. It secures negative liberty by protecting individuals against concrete interferences by the state and by others. ${ }^{151}$ And finally, housing safeguards republican liberty by reducing domination. Housing provides an important check on the state's power to police a person's most basic human acts and others' power to control an individual's opportunity to obey laws that regulate public property. ${ }^{152}$ Ultimately, access to housing constitutes a crucial gateway to liberty - positive, negative, and republican.

151 Waldron, "Homelessness and the Issue of Freedom", supra note 71; Barros, supra note 1 at 259-60.

152 Skolnik, "Regulated Differently", supra note 21 at 319-20. 